УДК 37.013.42:343.62:616-053.31

DOI 10.11603/2411-1597.2020.2.11243

\title{
ПРОФІЛАКТИКА ВІДМОВ МАТЕРІВ ВІД НЕМОВЛЯТ
}

\author{
I. В. Вовченко
}

Комунальний вищий навчальний заклад “Первомайський медичний коледж»

У статті наведено результати дослідження перебігу вагітності, використовуючи класифікацію переживання вагітності за Г. Г. Філіповою. Розкрито основні ознаки можливого ризику відмов від дитини матерями, які необхідно враховувати викладачам медичного коледжу у виховній роботі.

\section{PREVENTION OF MOTHER'S DISCLAIMER}

\section{V. Vovchenko}

\section{Municipal Higher Educational Institution "Pervomaysk Medical College”}

The article presents a classification of pregnancy experiences. The basic signs of a possible risk of child rejection, which should be considered in the educational work of the teachers of the medical college, are revealed.

Вступ. Материнство і дитинство належать до тих соціальних феноменів, які найбільш чутливі до соціально-економічних трансформацій у суспільстві. Свідченням цього $є$ велика кількість дітей, яких виховують поза межами рідної сім'ї, високий показник відмов породіль від немовлят. Причини такого явища - морально-етичні, психологічні, економічні. Однак причини і наслідки відмов від новонароджених не вичерпуються прямою залежністю від проблем економічного характеру, більш тісно вони пов'язані з суспільним життям і моральними цінностями. Тому важливу роль у вихованні відповідальності молоді до вирішення проблем раннього материнства виконують педагоги, які покликані враховувати поведінкові прояви переживання вагітності в дівчат, які можуть скласти групу ризику відмовниць.

Основна частина. Згідно з даними Міністерства охорони здоров'я України, кількість відмов від новонароджених у пологових будинках щороку зростає (в 2010 р. - 719 відмов, на кінець 2017 р. - 1246). Така ситуація $\epsilon$ свідченням наявності проблеми раннього соціального сирітства. Відтак не забезпечується одне з базових прав Конвенції ООН про права дитини право на сім'ю. Особливу роль у такій ситуації відіграє відмова жінок від новонароджених.

Особливим періодом у становленні материнства $\epsilon$ період вагітності, який розглядають психологи як один із критичних в житті кожної жінки і є важливим етапом при формуванні статевої ідентифікації. У цей період спостерігають актуалізацію невирішених у дитинстві психологічних проблем, загострюються внутрішні конфлікти та протиріччя. Прийняття рішення про відмову від дитини переважно виникає у жінок до ії народження. Як наголошують дослідники, в основі відмови лежить складний психологічний конфлікт, який у кожному конкретному випадку має свій зміст, але у результаті призводить до «придушення» інстинкту материнства [3].

Науковці зазначають, що у цей період жінка переживає психологічну кризу, в основі якої лежить боротьба мотивів - коли інстинктивному прагненню жінки до материнства та тиску суспільної моралі протидіють розпач і зневіра у власних силах та можливостях. Тому прийняття рішення залишити дитину в багатьох жінок супроводжується психічним напруженням, почуттям провини і власної гріховності. Саме тому жінки вдаються до певних психологічних форм захисту. В одних випадках - це раціоналізація, коли для самозахисту жінка наводить численні реалістичні та малореалістичні аргументи, які, з їі точки зору, виправдовують їі наміри. В інших випадках - домінують психологічні механізми витіснення, коли жінка спочатку гостро переживає емоційний шок від усвідомлення небажаної вагітності, а потім ніби «забуває» про

(c) І. В. Вовченко, 2020 
неї. Вона ставиться до майбутньої дитини байдуже, не включаючи її у сферу своєї самосвідомості [2].

Добровільна відмова матері від дитини передбачає наявність двох протилежних мотивів. Перший - звільнитися, щоб зберегти дитину, - має на меті наявність в уявленні жінки реальної чи навіяної загрози для майбутньої дитини. Другий - звільнитися від непотрібного тягаря, загрози для власного існування в реальних соціальних умовах [4]. У контексті нашого дослідження важливою є класифікація переживання вагітності, запропонована Г. Філіповою [6]. Авторка виокремлює такі види цього стану:

1. Адекватний. Ідентифікація вагітності без сильних та тривалих негативних емоцій.

2. Тривожний. Ідентифікація вагітності тривожна, зі страхами, які періодично поновлюються.

3. Ейфоричний. Спостерігають некритичне ставлення до можливих ускладнень вагітності та материнства. Зазвичай наприкінці вагітності з'являються ускладнення як сигнали неблагополуччя в очікуваннях післяпологового періоду.

4. Ігноруючий. Ідентифікація вагітності пізня, супроводжується почуттям прикрості та неприємності, фізичного дискомфорту. Активність в останньому триместрі не пов'язана з майбутньою дитиною.

5. Амбівалентний. Загальна симптоматика подібна до тривожного типу. Інтерпретація негативних емоцій переважно проявляється як страх за дитину чи перебіг пологів.

6. Нехтуючий. Ідентифікація вагітності супроводжується різкими негативними емоціями. Вагітність переживають як перешкоду, покарання. Наприкінці вагітності можливі сплески депресивних чи афективних станів.

Жінки, для яких притаманний ігноруючий, нехтуючий (відкидаючий) види переживання вагітності, складають групу ризику відмовниць.

На відміну від вищерозглянутого підходу, дослідники виокремлюють таку типологію матерів щодо свідомого чи неусвідомленого прийняття дитини [5]:

- ідеальна (свідоме і неусвідомлене прийняття);

- холодна (свідоме відхилення і неусвідомлене прийняття);

- амбівалентна (поєднання свідомого прийняття дитини з неусвідомленим відхиленням);

- катастрофічна (свідоме і неусвідомлене відхилення).

Розглядаючи проблему девіантного материнства, Р. Овчарова виокремлює такі типові психологічні особливості жінок із порушеною готовністю до материнства, як:

- емоційна та психологічна незрілість;

- низька толерантність до стресів;

- нестриманість афектів;

- емоційна нестабільність, егоцентризм;

- прагнення до незалежності;

- зосередженість на власних проблемах, переживання почуття несправедливості та нестачі любові;

- невирішеність дитячих і пубертатних конфліктів [5].

Доповнюючи цей психологічний портрет «відмовниць», інші дослідники зазначають, що серед них часто зустрічаються жінки з низьким рівнем контрольованості своїх імпульсів та потягів, різними особистісними аномаліями, такими проявами психологічного інфантилізму, як невміння передбачати очевидні життєві події та планувати своє життя, піддатливі тиску з боку друзів та родичів.

Останнім часом як причину відмови широко обговорюють психотичні розлади вагітної, в тому числі післяродова депресія. В ряді випадків у жінок із психопатичною схильністю, особливо при небажаній вагітності, може виникати патологічна ворожість до майбутньої дитини (мізопедія).

Розглядаючи причини девіантного материнства, не можна лишити поза увагою вікові характеристики жінок, оскільки в більшості досліджень віковий фактор визначається домінуючою причиною відмов матерів від немовлят.

У дослідженнях В. Брутман зазначає, що близько 15 \% складають юні матері (дівчата віком 14-18 років), більшість «відмовниць» - жінки віком до 25 років, близько 30 \% - у віковому діапазоні 30-50 років [2]. Юне материнство також розглядають як ризик відмов від новонароджених дітей. Більшість дослідників акцентує увагу на юному материнстві як одному з суттєвих факторів відмов. Це підтверджують дослідження, які проводили в усьому світі, в тому числі й у нашій країні. Вони вказують на особливе неблагополуччя позашлюбної народжуваності, зокрема серед неповнолітніх матерів.

На думку І. Братусь, юні матері - це дівчата та молоді жінки віком від 10 до 21 року, а юне материнство соціально-культурний феномен, сутність якого полягає у виношуванні, народженні, догляді та вихованні дитини матерями юного віку (до 21 року) [1].

Узагальнюючи результати досліджень, можна виокремити такі причини раннього материнства, як: 
- акселерація, ранній вступ у пубертатний період у поєднанні з лібералізацією норм і стандартів поведінки;

- необізнаність щодо жіночої фізіології та контрацепції (близько 45 \% неповнолітніх, які живуть статевим життям, не використовують контрацепцію);

- намагання втекти від почуття самотності, компенсація нелюбові з боку батьків чи осіб, які їх замінюють, бажання втілити наївну мрію про кохання з першого погляду;

- провокації з боку ровесників або старших (як правило неповнолітні дівчата вступають в статеві стосунки з більш старшими партнерами);

- викривлене уявлення про дорослість та бажання виглядати самостійними;

- викривлене задоволення потреби у самовираженні;

- вплив засобів масової інформації та субкультури референтної групи;

- відсутність ефективної системи превентивних програм;

- специфічні причини (зокрема, сексуальне насильство).

На основі вивчення випадків відмов юними матерями від новонароджених дітей науковці визначили таку психологічну типологію «юних матерів-відмовниць».

У першого типу юних матерів яскраво виражена особистісна незрілість, інфантилізм і пов'язана з ним несамостійність у прийнятті рішень, постійне почуття незахищеності, занижена критичність щодо себе. Вагітність у них виникає як результат необдуманої та часто ризикованої сексуальної поведінки.

До другого типу матерів автори зараховують молодих дівчат, для яких типові викривлення психосексуального розвитку. У них домінують агресивні стереотипи поведінки. Сексуальне життя таких юних жінок має проміскуітетний характер, незважаючи на занижений чуттєвий компонент.

У юних матерів третього типу домінує нерозвинутість вищих емоцій, знижена афективна чутливість, байдужість і, як результат, занижена здатність до формування емоційної прив'язаності. Такі дівчата мають гарний рівень інтелекту, добру логіку, прагматичні.

Важливою особистісною тенденцією четвертого типу «відмовниць» $є$ яскраво виражена афективна нестабільність у поєднанні зі слабкими вольовими процесами, легковажністю, підвищеною навіюваністю, які призводять до нездатності протистояти життєвим труднощам. Це переважно добродушні, поступливі дівчата. Вагітність у них виникає на фоні почуття закоханості, яка вирізняється переживаннями щастя, окриленості, захоплення.

П'ятий тип - досить рідкісний і не повною мірою самостійний. Психологічною основою для відмови від дитини у таких юних матерів $є$ яскраво виражена психічна недорозвинутість і пов'язана з цим соціальна безпорадність. Окремі з них спостерігаються у психіатрів із приводу олігофренії. Вагітність таких дівчат зазвичай має випадковий характер.

Така типологія, у свою чергу, може виступати підґрунтям при визначенні проблем юного материнства. Підсумовуючи сказане, на основі аналізу наукових досліджень можна виокремити такі причини відмов юних матерів від немовлят, як:

- психологічна та емоційна неготовність до материнства;

- інфантилізм;

- матеріальна залежність від батьків чи родичів;

- відсутність будь-яких професійних навичок;

- неможливість продовжувати навчання або проблеми працевлаштування;

- погані побутові умови.

Спеціалісти, які працюють з вагітними, часто називають різні ознаки можливого ризику відмов від дитини. На основі проведеного огляду та аналізу літературних і статистичних джерел нами виокремлено та конкретизовано кілька груп причин відмов матерів від немовлят:

- майбутня мати не має позитивної фіксації на дитині під час вагітності або вбачає у ній тягар;

- майбутня мати мала проблеми з прийняттям відповідальності та погано емоційно пристосовується;

- своєю поведінкою жінка ігнорує вагітність, веде несприятливий для плода спосіб життя;

- вагітність позашлюбна або небажана;

- шлюб нестабільний;

- вагітна юного віку і особисто незріла, потреба в дитині суперечить сімейним установкам батьківської родини;

- вагітна раніше вже відмовлялася від дітей чи утримує їх в інтернатних закладах;

- високий ризик народження дитини з фізичними дефектами;

- нереалістичні очікування вагітної щодо майбутньої дитини.

Висновки. Відмова матері від дитини - це форма девіантної поведінки, в основі якої комплекс соціальних, психологічних, економічних, педагогічних при- 
чин, які спричиняють порушення механізмів формування материнства. Така різноманітність причин вказує на необхідність індивідуального підходу в кожному окремому випадку з урахуванням як соціокультурних та економічних факторів, так і віку, психологічного

\section{СПИСОК ЛІТЕРАТУРИ}

1. Братусь І. В. Соціально-педагогічна робота з юними матерями у США та Великій Британії : дис. ... канд. пед. наук : 13.00 .05 / І. В. Братусь. - К., 2007. - 235 с.

2. Девиантное материнское поведение (опыт междисциплинарного анализа случая отказа от ребенка) / В. И. Брутман, А. Я. Варга, О. Т. Исупова и др. // Московский психотерапевтический журнал. - 1996. - № 4. C. 24-36.

3. Микиртумов Б. Е. Клиническая психиатрия раннего детского возраста / Б. Е. Микиртумов, А. Г. Кощавцев, С. В. Гречаный. - Спб. : Питер, 2001. - 256 с. стану та попереднього досвіду «відмовниці». Відтак викладачам медичного коледжу необхідно враховувати прояв студентками ознак можливого ризику відмов від дитини, щоб цілеспрямовано організовувати виховну роботу.

4. Никитина Т. Н. Отказ от материнства как социальная проблема : дис. ... канд. социол. наук : 22.00.04 / Т. Н. Никитина. - М., 2004. - 263 с.

5. Овчарова Р. В. Психология родительства : учебное пособие для студ. высш. учеб. заведений / Р. В. Овчарова. - М. : Академия, 2005. - 368 с.

6. Филиппова Г. Г. Психология материнства : учебное пособие / Г. Г. Филиппова. - М. : Изд-во Ин-та психотерапии, 2012. - 240 с.

Отримано 24.03.20 